\title{
Determinants and Regulating Processes in Bronchial Hyperreactivity
}

\author{
H. J. Neijens \\ Department of Pediatrics, subdivision of Pediatric Pulmonary Medicine, Erasmus University \\ and University Hospital Rotterdam/Sophia Children's Hospital, Rotterdam, The Netherlands
}

\begin{abstract}
Bronchial hyperresponsiveness (BHR) can be considered as a feature of asthma, although only a loose relationship is present with symptoms and severity of the disease. Epidemiology of BHR may inform about determining factors in BHR and its role as a risk factor. BHR is found already at a young age, mostly diminishes with age, and increases in many asthmatic patients after midlife. Genetic determinants are suggested by familial segregation and twin studies. Allergy, respiratory infections, and cigarette smoking are found to induce increase in BHR and to modify its degree at the long run. The mechanisms in BHR are being unraveled gradually. A chronic inflammation with an important role for eosinophils, mast cells, and others, is thought to modify bronchial mechanisms, such as smooth muscle, epithelium, and autonomic systems. Growing evidence supports that T lymphocytes are implicated and may determine many of the inflammatory cells, such as eosinophils, neutrophils, and mast cells.
\end{abstract}

Key words: Bronchial hyperreactivity_Epidemiology_Mechanism, T-cell system.

\section{Introduction}

The majority of asthmatic patients are found to have bronchial hyperreactivity (BHR) and this phenomenon is clearly a central feature of the pathophysiology of asthma. BHR is related to the occurrence and severity of asthmatic symptoms in general and to the bronchial reaction after various stimuli such as allergens, exercise, and cold air. A wealth of information has been accumulated about clinical aspects of BHR, but still relatively modest knowledge is present

Offprint requests to: Dr. H. J. Neijens, Sophia-Hospital, Academy Ziekenhuis, Gordelweg 160, 3038 GE Rotterdam, The Netherlands. 
about factors that influence BHR and about basic regulating processes. This presentation aims to consider the rapidly growing information about these aspects.

\section{Epidemiologic Studies}

The relationship of BHR with age and various variables may inform us about factors that determine or influence BHR.

BHR is found to be present already in very young children. Infants seem to have pronounced BHR. Le Souef et al. [1] found bronchial obstruction after relative low doses of histamine, using a chest squeezing technique. Similar findings have been found by Tepper [2]. These findings are consistent with the concept that infants are born with BHR or develop it soon after birth. The course of BHR from infancy into adulthood has been considered by Australian investigators. It was estimated that BHR decreased, but largely persisted and that about $60 \%$ of the subjects who had ceased wheezing still had BHR [3]. Gerritsen et al. [4] found a decrease in BHR in about two thirds and an increase in about one third of the patients in their adulthood as compared to BHR in their childhood (between 6.14 years of age). BHR in adulthood was related to lung function values in childhood and age of onset of respiratory symptoms. They concluded that the outcome of childhood asthma was primarily predicted by the initial degree of bronchial obstruction and BHR.

BHR appears to decline with age during childhood and early adulthood until reaching its lowest level during the fifth decade according to a study by Hopp et al. [5]. Subsequently, BHR increases with age during the sixth and seventh decades. Rijcken et al. [6] concluded from a large Dutch population study that BHR increased with age.

In a study of adults between 18 and 64 years of age BHR was found to increase strikingly with age among cigarette smokers, but actually decreased in atopic nonsmokers, perhaps reflecting the waning of atopy in advancing years. Adjustment for the level of pulmonary function is necessary for comparison of a wide range of BHR values, which is not well taken care for in most epidemiologic studies. This seriously compromises the conclusions and comparison between studies.

A concept may be constructed implying a high degree of BHR in young children which decreases slightly in part of them into adulthood. In the second half of life an increase in BHR can be observed in association with smoking and possibly other factors. Along with atopy, BHR actually decreased with age.

\section{Genetic Factors}

Duiverman et al. [7] studied groups of young children. A relatively high degree of BHR is present in asthmatic children, whereas a normal or slight degree was found in healthy children. Children without asthma who have borderline BHR 
turned out to have a positive family history for asthma and asthmatic children with a relatively low degree of BHR had a negative family history. The study of Duiverman and others points to a genetic determinant in the occurrence of BHR. Heredity as a factor in BHR is also suggested by twins and family aggregation data. Konig and Godfrey [8] have demonstrated a greater intrapair correlation of exercise-induced bronchus obstruction in monozygotic than among dizygotic twins. Hopp et al. [9] confirmed this in a relatively large selected population of twins, which was not the case in a small study by Zamel and colleagues [10]. Familial aggregation of BHR has been assessed in families of persons with asthma. Healthy relatives of asthma patients and infants with wheezy bronchitis were found to have an increased occurrence of exerciseinduced bronchus obstruction [11]. Also Townley et al. [12, 13] reached these conclusions. These human studies are in accordance with animal data involving rats [14] and dogs [15].

Thus, there is clearly an heritability component in BHR, but the genetic character is probably multifactorial and not likely to be dependent on a single gene. Longo et al. [16] found information to suggest them an autosomal-dominant pattern of inheritance.

\section{Environmental Influences}

A number of variables have been identified that are able to modify BHR, such as allergen reactions, viral infections, smoking, and polluted air. These factors are found to induce a temporarily increase in BHR, but their role in the generation of a persistent rise is less certain and awaits further study.

Allergy clearly has an effect on BHR, but the relationship between them is complicated. Allergen challenge and longitudinal studies with challenging and nonchallenging periods have indicated that BHR may increase due to an allergic late reaction in asthmatics. In population studies BHR is found to be associated with the presence of sensitization to common allergens [17-19].

Allergy and BHR may be connected either by genetically linked traits, or may interact by cellular and metabolic processes or both. Allergen-induced mediators, such as histamine and leukotrienes, as well as cell action by eosinophils and others, might well sensitize the bronchial mechanism to react in an augmented way.

Acute respiratory infections early in life (bronchiolitis, pneumonia) were found to be associated with the presence of BHR later on, in a study by Weiss and colleagues [20]. Those subjects who had croup or bronchiolitis or had repeated lower respiratory illnesses, had increased bronchial responsiveness as compared to those subjects who did not had such respiratory diseases. No clear relationship was detected between the presence of acute lower respiratory illness and atopy.

These and other observations suggest an interrelationship between infections, in particular bronchiolitis and BHR. This is not the case with aspecific lung injury in a random population. Several studies show that lung injury per se 
is not sufficient for induction of BHR, and that a genetic predisposition is probably necessary.

Cigarette smoking may cause heightened airway responsiveness, but this relationship seems to be evident only among persons with a sufficiently high cumulative exposure. This could be concluded from Burney et al. [19], Woolcock et al. [21], and Sparrow et al. [22], but not by the group of Van der Lende [23] which might be explained by a relatively low dose of smoking and the young mean age in this study.

A number of plausible mechanisms can be proposed for a direct causal relationship between smoking and BHR, namely, chronic airway inflammation, airway epithelial damage, and smoking-induced reduction in lung function.

The susceptibility to induce an increase in BHR and the development of chronic lung disease by all those environmental variables seems to be dependent, at least partially, on host factors. These factors are still difficult to define. The initial degree of BHR has been found to reffect a risk factor by several studies. This is substantiated by the studies of Postma et al. [24], who provided evidence indicating that the degree of BHR is related to the gradual loss in lung function. The decline in lung function is greater along with a higher degree of BHR.

The following concept of $B H R$ is supported by all this information. An endogenous component is present in BHR, which is probably largely genetically determined. In addition, certain environmental variables may induce a further augmentation in BHR. This susceptibility is probably dependent on host factors that are highly associated with the presence of asthma and probably linked to the genetic system.

\section{Mechanisms of BHR}

The causes of BHR are being unraveled step by step, although the responsible basic abnormality is still not elucidated. Along with research progress three stages can be considered.

\section{Anatomic and Functional Modifications in Bronchial Systems}

Anatomical and functional modifications in bronchial systems directly regulate bronchial diameter. Some reports produce evidence that airway smooth muscle from asthmatics exhibited increased contractile responses in vitro to agonists (histamine, methacholine and leukotriene $\mathrm{C}_{4}$ ) as compared to that of healthy controls $[25,26]$. However, few true asthmatics have been studied in this way.

Airway smooth muscle hyperplasia is present even in relatively mild asthmatics, possibly as a result of various growth factors released from inflammatory cells, such as platelet-derived and macrophage-derived growth factors. It seems likely the hyperplasia of airway smooth muscle would contribute to airway hyperrresponsiveness, and may explain the persistence of bronchial hyperresponsiveness after inflammation has subsided. 
Autonomic nervous control of the airways is complex and several studies have investigated the possibility that defects in autonomic control may contribute to bronchial hyperresponsiveness and the pathology of asthma. Several abnormalities of autonomic function, such as enhanced cholinergic and $\alpha$-adrenergic responses or reduced $\beta$-adrenergic responses, have been proposed.

Current thinking suggests that these abnormalities are likely to be secondary to the disease, rather than primary defects. It is possible that airway inflammation may interfere with autonomic control by several mediators and mechanisms [27].

Airway epithelial damage may be a critical feature of BHR and may explain how several different mechanisms, such as allergen exposure, virus infection, and ozone exposure, can lead to its development, since all these stimuli may lead to epithelial disruption. Epithelial disruption may contribute to BHR in a number of ways. Mechanical removal of epithelial cells in vitro results in increased responsiveness of airway smooth muscle to spasmogens $[28,29]$ and suggests that epithelial cells may release a relaxant factor by analogy with endothelial-derived relaxant factor in vessels. Damage of epithelium would thus remove the protective effect of this relaxant factor, leading to exaggerated bronchoconstrictor responses. Epithelial cells themselves may release inflammatory mediators, such as leukotriene $B_{4}$ and $15-H E T E$, which is chemotactic for inflammatory cells [30]. Epithelial damage will also expose sensory nerve endings, which may be activated by inflammatory mediators, leading to inflammation via an axon reflex mechanism [31].

\section{Inflammatory Processes in the Bronchi}

There is now considerable experimental evidence that induced BHR is associated with inflammation in the airways [32]. Histopathologic studies from asthmatic patients who have died during asthma attacks show that there is marked inflammation in the airways, with infiltration of inflammatory cells, particularly eosinophils, disruption of airway epithelium and mucus hypersecretion [33]. Similar pathologic changes have also been found in bronchial biopsies from asthmatics who are relatively mild [34] and suggest that airway inflammation may underlie BHR.

By bronchoalveolar lavage (BAL) several cell types are found, especially after provocation; these cells are eosinophils, neutrophils, mast cells, and lymphocytes. Wardley et al. [34] found an inverse relationship between BHR (PC20) and the percentage of mast cells, eosinophils, epithelial cells, and the amount of MBP. It now seems likely that several different cells are involved in the pathogenesis of asthma, and that these cells produce a variety of mediators that interact in a complex way to produce a number of pathologic effects that, together, contribute to BHR.

Macrophages are present throughout the respiratory tract, and the recent demonstration that they may be activated by IgE-dependent mechanisms has suggested that they may be involved in asthmatic inflammation [36]. They have the potency to produce and release a variety of mediators. Macrophages from 
asthmatics release increased amounts of mediators, such as thromboxane, prostaglandins, and platelet-activating factor (PAF).

Histologic studies suggest that eosinophil infiltration is a feature of asthmatic airways and differentiates asthma from other inflammatory conditions. Allergen inhalation results in a marked increase in eosinophils in bronchoalveolar lavage fluid at the time of the late reaction [37], and there is a relationship between peripheral eosinophilia and bronchial hyperresponsiveness [38].

Eosinophils release a variety of mediators, including leukotriene $\mathrm{C}_{4}$ and PAF, and basic proteins such as major basic protein, eosinophil cationic protein and eosinophil-derived neurotoxin, that are toxic to airway epithelium and other structures.

Neutrophil infiltration is characteristic of some animal models of asthma [39]. Neutrophils are particularly related to provocation with toxic factors such as ozone [40] and industrial agents, but are also found shortly after allergen inhalation before the eosinophils arrive. Although neutrophils are found to produce factor(s) that may induce BHR [41], their role in human asthma is less certain [42].

Many different mediators have been implicated in asthma and they may have a variety of affects on the airways that account for many of the pathologic features of asthma. Thus, mediators such as histamine, prostaglandins, and leukotrienes contract airway smooth muscle, increase microvascular leakage, increase mucus secretion, and attract other inflammatory cells. It is therefore possible that interaction between inflammatory mediators might account for BHR.

PAF, like antigen, stimulates accumulation of eosinophils in lung [43] and in the skin of atopic subjects [44]. This selective attraction of eosinophils might explain how PAF can produce such a prolonged increase in responsiveness, since eosinophils may lead to damage and shedding of airway epithelium as discussed above. Since eosinophils themselves are a rich source of PAF [45], they can attract further eosinophils and there is the potential for a continued inflammation. PAF has other properties that may be relevant in asthma. In animals, PAF is a potent inducer of airway microvascular leak, being the most potent agent so far described [46]. This may lead to airway edema and plasma extravasation which may be involved in the creation of BHR [47].

\section{Immunoregulating Factors}

The study of immunoregulating factors is the final step in the elucidation of the mechanisms and this approach has just started. The concept is that immune factors related to $\mathrm{T}$ lymphocytes have an important role to regulate cellular responses by eosinophils and other aspecific cells and thus determine the occurrence and degree of bronchial inflammation.

Infiltration by $\mathrm{T}$ lymphocytes $\left(\mathrm{CD}_{3}^{+} / \mathrm{CD}_{4}^{+}\right)$together with $\mathrm{T}$-cell activation (IL-2 receptor) was found in association with allergen-induced late-phase skin 
reaction in human atopic subjects by Frew et al. [48]. These changes were accompanied by eosinophil infiltration and activation.

Bronchoalveolar lavage studies of the human late asthmatic reaction have revealed the presence of increased numbers of eosinophils and lymphocytes during the late response, whereas no such changes were seen in isolated early responders [49]. Gonzalez et al. [50] studied T-cell subsets in BAL and blood. BAL lymphocytes increased until 6-12\% of the cells in both BAL and blood isolated early and dual responders after allergen challenge. In the dual responders $C_{4}$ and $C D_{8}$ increased, whereas in the isolated early reactions no change in $\mathrm{CD}_{8}$ and thus decrease in the $4: 8$ ratio was present in BAL. The absence of a $\mathrm{CD}_{8}$ rise in late-phase responders raises the possibility that $\mathrm{CD}_{8} \mathrm{~T}$ lymphocytes control the occurrence of late bronchial reactions.

Effects of T-cell activation have been found in several other cell types, namely, IL-2 and HLA-DR receptor activation on endothelial cells and $\mathrm{CD}_{4}$ antigen on epidermal Langhans cells. Both provide indirect evidence of $\gamma$ interferon secretion from activated $\mathrm{T}$ cells. A strong association was detected linking $\mathrm{CD}_{4}^{+} \mathrm{T}$ lymphocyte numbers with the number of activated eosinophils in the study by Frew et al [48].

These findings suggest that $\mathrm{CD}_{4}^{+} \mathrm{T}$ lymphocytes are attracted to sites of allergic inflammation and that these cells and their products may contribute to the pathogenesis of chronic allergic inflammation. Cytokines such as $\gamma$-interferon have many actions, including activation of macrophages for subsequent elaboration of eosinophil activation factors. There have been several reports of a defect in suppressor cell function in asthma $[51,52] . \mathrm{CD}_{8}^{+} \mathrm{T}$ cells produce a histamine-induced suppressor factor that inhibits lymphocyte proliferation and lymphokine production.

The clinical relevance of $\mathrm{T}$ lymphocytes in asthma is further supported by the observation showing that the number of $\mathrm{T}$ lymphocytes expressing HLADR and IL-2 receptors indicating cell activation, was increased with exacerbations [53].

A growing body of information suggests that eosinophil differentiation and proliferation is controlled by cytokines including IL-5- and T-lymphocyte-derived eosinophil colony stimulating factors both in humans and animals [54$56]$.

An action of $\mathrm{T}$ lymphocytes on neutrophil activation was put forward by Tsai et al. [57] who detected a lymphocyte-derived factor. After induction by anti-CD $\mathrm{CD}_{4}$ antibodies, $\mathrm{LTB}_{4}$ generation by neutrophils increased by $15 \%$ $350 \%$.

Good evidence supports now that $\mathrm{T}$ lymphocytes are present and active in allergic reactions in the skin and in the bronchi. T lymphocytes are found to have the potency to induce eosinophil, neutrophil, and macrophage activation, for which actions in vivo evidence has been detected. Inadequate actions of $\mathrm{CD}_{8}^{+} \mathrm{T}$ lymphocytes, probably a specific subset, might also be critical in asthmatic reactions. Since the actions of T lymphocytes are under control of immunoresponse genes, genetic factors might well guide asthmatic reactions and BHR along this line. 


\section{References}

1. Le Souef PN, Geelhoed GC, Turner DJ, Morgan SEG, Landau LJ (1989) Response of normal infants to inahled histamine. Am Rev Respir Dis 139:62-66

2. Tepper RS (1987) Airway reactivity in infants: a positive response to methacholine and metaproterenol. J Appl Physiol 62:1155-1159

3. Martin AJ, Landau LI, Phelan PD (1982) Asthma from childhood at age 21: the patient and his disease. Br Med J 284:380-382

4. Gerritsen J, Koëter GH, Postma DS, Schouten JP, Knol K (1989) Prognosis of asthma from childhood to adulthood. In: Thesis of Gerritsen J. Van Gorcum, Assen, 1989

5. Hopp RJ, Bewtra A, Nair NM, Townley RG (1985) The effect of age on methacholine response. J Allergy Clin Immunol 76:609-613

6. Rijcken B, Schouten JP, Weiss ST, Speizer FE, van der Lende R (1987) The relationship of nonspecific bronchial responsiveness to respiratory symptoms in a random population sample. Am Rev Respir Dis 136:62-68

7. Duiverman EJ, Neijens HJ, van Strik R, Affourtit MJ, Kerrebijn KF (1987) Lung function and bronchial responsiveness in children who had infant bronchiolitis. Ped Pulmonol 3:38-44

8. Konig P, Godfrey S (1974) Exercise-induced bronchial lability in monozygotic (identical) and dizygotic (non-identical) twins. J Allergy Clin Immunol 54:280-287

9. Hopp RJ, Bewtra AK, Watt GD, Nair NM, Townley RG (1984) Genetic analysis of allergic disease in twins. $J$ Allergy Clin Immunol 73:265-270

10. Zamel N, Leroux M, Vanderdoelen JL (1984) Airway response to inhaled methacholine in healthy non-smoking twins. J Appl Physiol 56:936-939

11. Konig P, Godfrey S (1973) Prevalence of exercise-induced bronchial lability in families of children with asthma. Arch Dis Child 48:513-518

12. Townley RG, Bewtra AK, Nair NM, Brodkey FD, Watt GD, Burke KM (1979) Methacholine inhalation challenge studies. J Allergy Clin Immunol 64:569-574

13. Townley RG, Bewtra AK, Wilson AF, et al. (1986) Segregation analysis of bronchial response to methacholine inhalation challenge in families with and without asthma. $J$ Allergy Clin Immunol 77:101-107

14. Pauwels R, van der Straeten M, Weyne J, Bazin H (1983) An animal model for the study of the relationship between non-specific bronchial reactivity and imunological hypersensitivity. Agents Actions 13(Suppl):55-63

15. Hirshman CA, Downes H, Veith L (1984) Airway responses in offspring of dogs with and without airway hyperreactivity. J Appl Physiol 56:1272-1277

16. Longo G, Strinati R, Poli F, Furni F (1987) Genetic factors in nonspecific bronchial hyperreactivity. An epidemiologic study. Am J Dis Child 141:331-334

17. Witt C, Stuckey MS, Woolcock AJ, Dawkins RL (1986) Positive allergen prick tests associated with bronchial histamine responsiveness in an unselected population. J Allergy Clin Immunol 77:698-702

18. Cockson WO, Musk AW, Ryan G (1986) Association between asthma history, atopy and nonspecific bronchial responsiveness in young adults. Clin Allergy 16:425-432

19. Burney PG, Britton JR, Chinn S, et al. (1987) Descriptive epidemiology of bronchial reactivity in an adult population: results from a community study. Thorax 42:38-44

20. Weiss ST, Tager IB, Munoz A, Speizer FE (1985) The relationship of respiratory infections in early childhood and the occurrence of increased levels of bronchial responsiveness and atopy. Am Rev Respir Dis 131:573-578

21. Woolcock AJ, Peat JK, Salome CM (1987) Prevalence of bronchial hyperresponsiveness and asthma in a rural adult population. Thorax 42:361-368

22. Sparrow D, O'Connor G, Colton T, Barry CL, Weiss ST (1987) The relationship of nonspecific bronchial responsiveness to the occurrence of respiratory symptoms and decreased levels of pulmonary function. The normative aging study. Am Rev Respir Dis 135:1255-1260

23. Rijcken B, Schouten JP, Weiss ST, Speizer FE, van der Lende R (1988) The relationship between airway responsiveness to histamine and pulmonary function level in a random population sample. Am Rev Respir Dis 137:826-832 
24. Postma DS, de Vries K, Koëter GH, Sluiter HJ (1956) Independent influence of reversibility of airflow obstruction and nonspecific hyperreactivity on the long-term course of lungfunction in chronic airflow obstruction. Am Rev Respir Dis 134:275-280

25. De Jongste JC, Mons H, Bonta Il, Kerrebijn KF (1987) In vitro responses of airways from an asthmatic patient. Eur J Respir Dis 71:23-29

26. Schellenberg RR, Foster A (1984) In vitro responses of human asthmatic airway and pulmonary vascular smooth muscle. Int Arch Allergy Appl Immunol 75:237-241

27. Barnes PJ, Grandordy B, Page CP, Rhoden KJ, Robertson DN (1986) The effect of PAF induced bronchial hyperreactivity on beta-adrenoreceptor function. $\mathrm{Br} \mathrm{J}$ Pharmacol 89:742P

28. Barnes PJ (1985) Clinical studies with calcium antagonists in asthma. Br J Clin Pharmacol 20:895S-995S

29. Flavahan NA, Aarhus LL, Rimele TJ, Vanhoutte PM (1985) Respiratory epithelium inhibits bronchial smooth muscle tone. J Appl Physiol 58:834-838

30. Hunter JA, Finkbeiner WE, Nadel JA, Goetzl EJ, Holtzman MJ (1985) Predominant generation of 15-lipoxygenase metabolites of arachidonic acid by epithelial cells from human trachea. Proc Natl Acad Sci USA 82:4633-4637

31. Barnes PJ (1986) Asthma as. an axon reflex. Lancet 1:242-245

32. Chung KF (1986) Role of inflammation in the hyperreactivity of the airways in asthma. Thorax 41:657-662

33. Dunnill MS (1960) The pathology of asthma with special reference to changes in the bronchial mucosa. J Clin Pathol 13:27-33

34. Laitinen LA, Heino M, Laitinen A, Kava T, Haahtela T (1985) Damage of the airway epithelium and bronchial reactivity in patients with asthma. Am Rev Respir Dis 131:599-606

35. Wardlaw AJ, Dunette S, Gleich GJ, Collins JV, Kay AB (1988) Eosinophils and mast cells in bronchoalveolar lavage in subjects with mild asthma. Am Rev Respir Dis 137:62-69

36. Joseph $M$, Tonnel AB, Tarpier G, Capron A (1983) Involvement of immunoglobulin $E$ in the secretory process of alveolar macrophages from asthmatic patients. $J$ Clin Invest 71:221-230

37. De Monchy JGR, Kauffman HF, Venge P, Koëter GH, Jansen HM, Sluiter HJ, de Vries K (1985) Bronchoalveolar eosinophils during allergen-induced late asthmatic reactions. Am Rev Respir Dis 131:373-376

38. Frigas E, Gleich GJ (1986) The eosinophil and the pathology of asthma. J Allergy Clin Immunol 77:527-537

39. O'Byme PM, Walters EH, Gold BD, et al. (1984) Neutrophil depletion inhibits airway hyperresponsiveness induced by ozone exposure in dogs. Am Rev Respir Dis 130:214-219

40. Fabbri LM, Aiwaza H, Alpert SE, Walters EH, O'Byrne PM, Gold BD, Nadel JA, Holtzman MJ (1984) Airway hyperresponsiveness and changes in cell counts in bronchoalveolar lavage after ozone exposure in dogs. Am Rev Respir Dis 129:288-291

41. O'Byrne PM, Walters EH, Gold BD, Aiwaza HA, Fabbri LM, Alpert SE, Nadel JA, Holtzman MJ (1984) Neutrophil depletion inhibits airway hyperresponsiveness induced by ozone exposure. Am Rev Respir Dis 130:214-219

42. Hulbert WM, Mclean T, Hogg JC (1985) The effect of acute airway inflammation on bronchial reactivity in guinea pigs. Am Rev Respir Dis 132:7-11

43. Lellouch-Tubiana A, Lefort J, Pirotzky E, Vargaftig BB, Pfister A (1985) Ultrastructural evidence for extravascular platelet recruitment in the lung upon intravenous injection of platelet activating factor (PAF-acether) to guinea-pigs. Br J Exp Pathol 66:345-355

44. Henocq E, Vargaftig BB (1986) Accumulation of eosinophils in response to intracutaneous PAF-acether and allergens in man. Lancet 1:1378-1379

45. Lee TC, Lenihan DJ, Malone B, Roddy LL, Wasserman SI (1984) Increased biosynthesis of platelet activating factor in activated human eosinophils. J Biol Chem 259:5526-5530

46. Evans TW, Chung KF, Barnes PJ (1986) Platelet activating factor increases vascular permeability in guinea-pig airways. Clin Sci 71:1P

47. Persson CGA (1986) The role of microvascular permeability in the pathogenesis of asthma. Eur J Respir Dis 68(Suppl 144): 190-216

48. Frew AJ, Corrigan CJ, Maestraelli P, Tsai JJ, Kurihara K, O’Hehir RE, Hartnell A, Cromwell $\mathrm{O}$, Kay $\mathrm{AB}(1989) \mathrm{T}$-lymphocytes in allergen-induced late-phase reactions and asthma. Int Arch Allergy Appl Immunol 8:63-67 
49. De Monchy JGR, Kauffman HF, Venge P, et al. (1985) Bronchoalveolar eosinophilia during allergen induced late asthmatic reactions. Am Rev Respir Dis 131:373-376

50. Gonzalez MC, Diaz P, Galleguillos TR, Ancic P, Cromwell D, Kay AB (1987) Allergeninduced recruitment of bronchoalveolar helper (OKT4) and suppressor (OKT8) T-cells in asthma. Am Rev Respir Dis 138:600-604

51. Jefield D, Kivity S, Feierman E, Topilosky M, Koperman D (1985) Effects of in vitro colchicine and oral theophylline on suppressor cell function of asthmatic patients. Clin Exp Immunol 61:360-367

52. Rocklin RE, Sheffer AL, Greineder DR, Melmon KL (1980) Generation of antigen-specific suppressor cells during allergy desensitization. N Engl J Med 302:1213-1219

53. Corrigan CJ, Hartnell A, Kay AB (1988) T-lymphocyte activation in acute severe asthma. Lancet i:1129-1132

54. Campbell HD, Tucker WQJ, Hort J, et al. (1987) Molecular cloning, nucleotide sequence and expression of the gene encoding human eosinophil differentiation factor (IL-5). Proc Natl Acad Sci USA 84:6629-6633

55. Raghavachar A, Fleischer S, Frickhofen N, et al. (1987) T-lymphocyte control of human eosinophilic granulopoiesis clonal analysis of an idiopathic hypereosinophilic syndrome. J Immunol 139:3753-3758

56. Lopesz AF, Sanderson CT, Gramble JR, et al. (1988) Recombinant human interleukin-5 is a selective activator of human eosinophil function. J Exp Med 167:219-224

57. Tsai JJ, Maestrelli P, Fitzharris P, et al. (1987) A lymphocyte derived activity which enhances IgG-dependent release of leucotriene $\mathbf{B}_{4}$ from human neutrophils. $\mathrm{J}$ Allergy Clin Immunol 79:167 